\title{
Cell Phone and Cancer Risk
}

\author{
Turgut Kaçan ${ }^{1}$, Dilek Erdem², Selen Baloglu Kaçan ${ }^{3}$ \\ ${ }^{1}$ Afyonkarahisar State Hospital, Department of Medical Oncolgy, Afyonkarahisar \\ ${ }^{2}$ Samsun Medical Park Hospital, Department of Medical Oncolgy, Samsun \\ ${ }^{3}$ Afyonkarahisar State Hospital, Depatment of Internal Medicine, Afyonkarahisar \\ kacanturgut@gmail.com
}

\begin{abstract}
Thanks to the technology, mobile devices including cell phones have become an integral part of the modern life. Therefore, public concern pertaining to short-term and long-term possible adverse effects of using cell phone and electromagnetic radiation exposure of it is growing rapidly. There are various studies by which the positive and negative results have been demonstrated. The relationship between cell phone exposure and developing cancer risk has been still unclear. This review presents the relationship between cell phone use and cancer risk and declaration of some organisations.
\end{abstract}

\section{INTRODUCTION}

Thanks to advances in industrial and technological field, cell phones have become an integral part of the modern life and available for users because of the falling costs. Within this perspective, it leads to the rise of the number users in many countries as well as Turkey. Public concern pertaining to possible advers effects especially causing cancer due to electromagnetic field (EMF) exposure from cell phone is growing rapidly [1].

Electromagnetic field is separated into 3 categories according to frequencies. These are non-ionizing, ionizing and ionizing-particule radiations. The EMF category of cell phone is non-ionizing radiation. Non-ionizing radiation refers to any type of electromagnetic radiation that does not carry enough energy to ionize atoms or molecules [1-3]. Specific absorption rate (SAR) is a measure of the rate at which energy is absorbed by the human body when exposed to a radiofrequency (RF) EMF. It has units of watts per kilogram $(\mathrm{W} / \mathrm{kg})$. Although the limit of SAR values varies between 0.008 and 4.2 $\mathrm{W} / \mathrm{kg}$, the average of SAR is $0.13-1.4 \mathrm{~W} / \mathrm{kg}$ [4]. Accepted upper limit of SAR value of the cell phone is $0.1 \mathrm{~W} / \mathrm{kg}$. As known, cell phones are used for communnication by transmitting radio frequency. Such radioation exposure is not only derived from cell phones but also derived from $\mathrm{Wi}-\mathrm{Fi}$, television, and radio transmitters [5]. It is known that EMF exposure can cause damage on chemical bonds but not on humans' deoxyribonucleic acid (DNA) [6]. Nevertheless, EMF could be absorbed by the tissues [5]. The cause-effect relationship and mechanism have been unclear. Because of the public concern about EMF exposure, it has been under investigation.

\section{Cell Phone Exposure in a Short-Term}

To understand the short-term effect of EMF exposure on physiological changes, cognitive performance and pathological setting have been investigated. The studies have reported that headache, dizziness, tachycardia could occur due to keeping the cell phone close to the body. However, these symptoms were not significant $[7,8]$. Up to now any convincing evidences have not been shown except for the tissue heating effect [9].

\section{Cell Phone Exposure in a Long-Term}

The link between potential long-term exposure of EMF and brain tumors and cancer have been searched on cell phones. Although many animal studies have been performed to try to search the longterm effects of EMF exposure, they could not able to demonstrate an increase in developing cancer. Fifty-minute or long cell phone exposure could cause an increase in brain glucose metabolism despite the fact that clinical importance of increased brain glucose metabolism have not known $[10,11]$. Few studies trying to search the relationship between EMF exposure and long-term health effects have showed that some chromosomal and genetic damages could be detected. Therefore, consequences of 
such damages of having long-term EMF exposure could be a bit risky for increased neoplasia or agerelated diseases. For instance, using long hours ( $\geq 100$ hours of cumulative use) and starting to use cell phone before the age of 20 can cause a higher risk for developing intracranial tumors and neuropyschiatric problems[12-14].

\section{Cell Phone and Cancer}

The first concern on EMF exposure and related issues especially cancer dates back to three or four decades but the evidence of association between them is weak and limited. That's why The International Agency for Research on Cancer has classified it as Group 2B (Possibly Carcinogenic). Therefore, information on using of the cell phone use about increased cancer risk is contradictory [15]. In order to understand the association, many investigations have been performed. In a metaanalysis consisted of 17 articles on intracranial tumors and cell phone use published in 2012 [16, 17]. The link could not be demonstrated. Evidence for a relationship between cancer and cell phone use has not been shown in an extended study [18].

Concerning this subject, the largest study, INTERPHONE, conducted by researhcers from 14 countries, searched the association of cell phone use, duration of cell phone use and intracranial tumors such as meningioma and gliomas. They found no significant relationship [19]. They only reported a little increase in developing glioma risk when using long term but then added that those findings had to be investigated and supported. The association between EMF exposure and intracranial tumors was not demonstrated by other studies either. [20, 21].

Studies evaluating the relation with cranial tumors have revealed positive correlation in long-term use. The positive correlation was found between cancer risk and at least 10 year-use by taking survey and assessing the retrospective data [22, 23].

As there have been uncertainties about this subject for decades, some organizations such as World Health Organization (WHO), The American Cancer Society (ACS), and The U.S Centers for Disease Control and Prevention (CDC) need to state declarations. WHO declared that no cancer event have been developed. ACS states that there could be a risk but not strong enough. CDC declared that no scientific evidence was reported [11].

\section{CONCLUSION}

Thanks to advances in industrial and technological fields, mobile devices especially cell phones have become available for users because of the falling costs. Although many studies have tried to look for the relationship between RF exposure of cell phone and cancer, they have pointed the risks of longterm cell phone use ( $\geq 100$ hours $/ \geq 10$ years) causing cancer and/or age-related diseases. Therefore, cell phone users have been concerned about possible health effects of long-term cell phone use due to the contradictory results.

\section{REFERENCES}

[1] R.W. Habash, J.M. Elwood, D. Krewski, W.G. Lotz, J.P. McNamee, F.S. Prato, Recent advances in research on radiofrequency fields and health: 2004-2007, Journal of Toxicology and Environmental Health, Part B, 12 (2009) 250-288.

[2] I. Trošić, I. Pavičić, Disturbance of cell proliferation in response to mobile phone frequency radiation, Archives of Industrial Hygiene and Toxicology, 60 (2009) 109-115.

[3] S. Kılıçkap, E. Erdiş, Düşük frekanslı elektromanyetik alan, cep telefonları, baz istasyonları ve kanser riski, Cumhuriyet Medical Journal, 35 (2013) 311-317.

[4] A. Aslan, N.H. Aydoğan, T. Atay, S. Çömlekçi, The effects of electromagnetic field exposure at short and long term of $900 \mathrm{mhz}$ frequency emitted from mobile phones on rat bone tissue, Dicle Medical Journal, 38 (2011) 452-457.

[5] A. Dhami, Study of electromagnetic radiation pollution in an Indian city, Environmental monitoring and assessment, 184 (2012) 6507-6512.

[6] Y.-x. Liu, G.-q. Li, X.-p. Fu, J.-h. Xue, S.-p. Ji, Z.-w. Zhang, Y. Zhang, A.-m. Li, Exposure to $3 \mathrm{G}$ mobile phone signals does not affect the biological features of brain tumor cells, BMC public health, 15 (2015) 764. 
[7] F. Malek, K. Rani, H. Rahim, M. Omar, Effect of Short-Term Mobile Phone Base Station Exposure on Cognitive Performance, Body Temperature, Heart Rate and Blood Pressure of Malaysians, Scientific reports, 5 (2015).

[8] V.T. Ahamed, N. Karthick, P.K. Joseph, Effect of mobile phone radiation on heart rate variability, Computers in Biology and Medicine, 38 (2008) 709-712.

[9] M. Röösli, Radiofrequency electromagnetic field exposure and non-specific symptoms of ill health: a systematic review, Environmental research, 107 (2008) 277-287.

[10] N.D. Volkow, D. Tomasi, G.-J. Wang, P. Vaska, J.S. Fowler, F. Telang, D. Alexoff, J. Logan, C. Wong, Effects of cell phone radiofrequency signal exposure on brain glucose metabolism, Jama, 305 (2011) 808-813.

[11] J.K. Meena, A. Verma, C. Kohli, G.K. Ingle, Mobile phone use and possible cancer risk: Current perspectives in India, Indian journal of occupational and environmental medicine, 20 (2016) 5.

[12] T.J. Prihoda, Genetic damage in human cells exposed to non-ionizing radiofrequency fields: a meta-analysis of the data from 88 publications (1990-2011), Mutation Research/Genetic Toxicology and Environmental Mutagenesis, 749 (2012) 1-16.

[13] L. Hardell, M. Carlberg, Mobile phone and cordless phone use and the risk for glioma-Analysis of pooled case-control studies in Sweden, 1997-2003 and 2007-2009, Pathophysiology, 22 (2015) 1-13.

[14] G. Abdel-Rassoul, O.A. El-Fateh, M.A. Salem, A. Michael, F. Farahat, M. El-Batanouny, E. Salem, Neurobehavioral effects among inhabitants around mobile phone base stations, Neurotoxicology, 28 (2007) 434-440.

[15] V.G. Khurana, L. Hardell, J. Everaert, A. Bortkiewicz, M. Carlberg, M. Ahonen, Epidemiological evidence for a health risk from mobile phone base stations, International journal of occupational and environmental health, (2013).

[16] S. Lagorio, M. Röösli, Mobile phone use and risk of intracranial tumors: a consistency analysis, Bioelectromagnetics, 35 (2014) 79-90.

[17] M. Röösli, P. Frei, E. Mohler, K. Hug, Systematic review on the health effects of exposure to radiofrequency electromagnetic fields from mobile phone base stations, Bulletin of the World Health Organization, 88 (2010) 887-896.

[18] J. Schüz, R. Jacobsen, J.H. Olsen, J.D. Boice, J.K. McLaughlin, C. Johansen, Cellular telephone use and cancer risk: update of a nationwide Danish cohort, Journal of the National Cancer Institute, 98 (2006) 1707-1713.

[19] I.S. Group, Brain tumour risk in relation to mobile telephone use: results of the INTERPHONE international case-control study, International journal of epidemiology, (2010) dyq079.

[20] L. Klaeboe, K.G. Blaasaas, T. Tynes, Use of mobile phones in Norway and risk of intracranial tumours, European Journal of Cancer Prevention, 16 (2007) 158-164.

[21] T. Takebayashi, N. Varsier, Y. Kikuchi, K. Wake, M. Taki, S. Watanabe, S. Akiba, N. Yamaguchi, Mobile phone use, exposure to radiofrequency electromagnetic field, and brain tumour: a case-control study, British journal of cancer, 98 (2008) 652-659.

[22] S. Lönn, A. Ahlbom, P. Hall, M. Feychting, Mobile phone use and the risk of acoustic neuroma, Epidemiology, 15 (2004) 653-659.

[23] L. Hardell, M. Carlberg, F. Soderqvist, K. Hansson Mild, Meta-analysis of long-term mobile phone use and the association with brain tumours, International journal of oncology, 32 (2008) 1097-1104. 